\title{
ANALISIS LAJU EROSI DAS CITARUM DARI HULU HINGGA KAWASAN MUARA MENGGUNAKAN SISTEM DINAMIK
}

\section{ANALYSIS OF EROSION RATE OF THE CITARUM WATERSHED FROM THE UPSTREAM TO THE ESTUARY AREA USING DYNAMIC SYSTEM}

\author{
Hari Prihatno ${ }^{1}$ \& Johar Setiyadi ${ }^{2}$
}

${ }^{1}$ Peneliti Pusat Riset Kelautan, BRSDM, KKP

${ }^{2}$ Sekolah Tinggi Teknologi Angkatan Laut (STTAL),Hidros, TNI-AL

e-mail : hari.prihatno@gmail.com

Diterima tanggal: 10 Mei 2021 ; diterima setelah perbaikan: 30 Agustus 2021 ; Disetujui tanggal: 31 Agustus 2021

\begin{abstract}
ABSTRAK
Daerah Aliran Sungai (DAS) Citarum merupakan DAS terbesar yang ada di Jawa Barat. Sedimentasi waduk, dan banjir musiman merupakan permasalahan yang sering terjadi dan merupakan akibat dari erosi dan sedimentasi yang berkepanjangan pada DAS Citarum. Erosi tanah oleh air dapat terjadi akibat tumbukan butiran tanah oleh air dan akibat aliran air permukaan. Tujuan dari tulisan ini adalah memprediksi seberapa besar laju erosi tahunan pada DAS Citarum dengan memanfaatkan pemodelan Power Sim. Sebagai data inputan untuk model digunakan metode Universal Soil Loss Equation (USLE), adapun untuk mengetahui laju erosi tahunan yang dinyatakan dalam ton $/ \mathrm{km}^{2} /$ tahun, dibutuhkan perhitungan data indeks kemiringan lereng, nilai tata guna tanah, erodibilitas dan erosivitas. Hasil perhitungan prediksi hingga 100 tahun menunjukkan laju erosi terkecil secara garis besar berada pada area muara dengan nilai laju erosi lebih dari 60 ton $/ \mathrm{km}^{2} /$ tahun, sementara laju erosi lebih besar dari 200 ton $/ \mathrm{km}^{2} /$ tahun dengan prediksi perhitungan 100 tahun kedepan mendominasi area hulu DAS Citarum.
\end{abstract}

Kata kunci: Laju erosi, DAS Citarum, Hulu, Muara, Sistem Dinamik.

\section{ABSTRACT}

Citarum watershed is the largest watershed in West Java. Reservoir sedimentation and seasonal flooding are common problems and are a result of prolonged erosion and sedimentation in the Citarum watershed. Erosion of soil by water can occur due to collisions of soil granules by water and due to surface water flow. The purpose of this paper is to predict how much the annual erosion rate in the Citarum watershed by utilizing Power Sim modeling. As input data for the model used the Universal Soil Loss Equation (USLE) method, as for finding out the annual erosion rate expressed in tons $/ \mathrm{km}^{2} /$ year, it is necessary to calculate the slope index data, the value of land use, erodibility and erosivity. Predictive calculation results until 100 years show the smallest erosion rate in broad outline is in the Estuary area with an erosion rate of more than 60 tons $/ \mathrm{km}^{2} / y e a r$, while the erosion rate is greater than 200 tons $/ \mathrm{km}^{2} /$ year with the prediction of the calculation until 100 years dominating the upstream area of the Citarum watershed.

Keyword: Erosion rate, Citarum watershed, upstream area, Estuary area, Dynamic System. 


\section{PENDAHULUAN}

Daerah Aliran Sungai (DAS) Citarum merupakan DAS terbesar yang ada di Jawa Barat. Kondisi topografi pada area hulu DAS Citarum didominasi oleh pegunungan dengan kelerengan lahan cukup curam dengan tutupan lahan berupa hutan, sedangkan kondisi topografi pada bagian tengah dan muaranya cenderung berupa dataran yang luas dengan tata guna lahan yang mendominasi berupa pertanian dan pemukiman hingga ke area muaranya. Terdapat 3 Waduk Besar (Saguling, Cirata, dan Jatiluhur). Sebagai Sumber air irigasi pertanian 300.000 Ha dan juga sebagai sumber air minum untuk Bandung, Cimahi, Cianjur, Purwakarta, Bekasi, Karawang, Jakarta. Sedimentasi waduk, dan banjir musiman merupakan permasalahan yang sering terjadi dan merupakan akibat dari erosi dan sedimentasi yang berkepanjangan pada DAS Citarum. Pada tata guna lahan DAS Citarum Hulu untuk 1994 dan 2001, terjadi perubahan ekstrem di bagian selatan Jawa Barat (sekitar hulu sungai Citarum) berupa konversi hutan menjadi tanah terbuka (semak, belukar atau lahan kering). Konversi hutan menjadi lahan terbuka dengan luas yang memiliki dampak spasial yang berarti berada pada wilayah tersebut menyebabkan peningkatan laju ekspor sedimen tahunan yang melebihi $100 \mathrm{ton} / \mathrm{km}^{2}$ (Poerbandono, 2006).

Erosi adalah hilangnya lapisan tanah dari suatu tempat

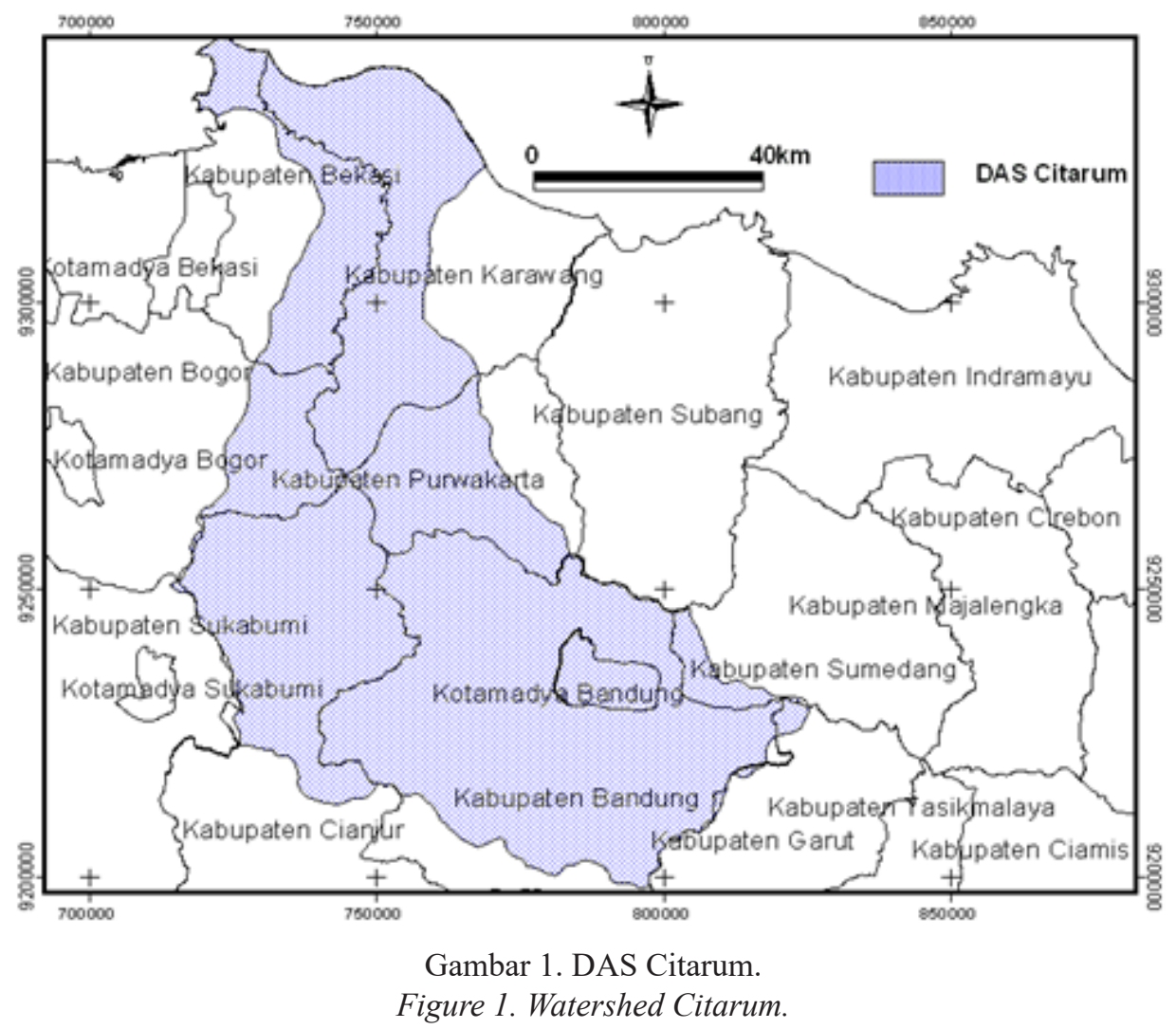

JURNAL KELAUTAN NASIONAL, Vol 16, No 2, Agustus 2021, Hal. 111-122

yang diangkut ke tempat lain oleh air atau angin. Di daerah beriklim basah, erosi oleh air lebih dominan, sedangkan di daerah beriklim kering, seperti daerah gurun, erosi oleh angin lebih dominan. Erosi menyebabkan hilangnya lapisan tanah bagian atas yang subur, serta menyebabkan berkurangnya kemampuan inflitrasi tanah. Tanah yang terangkut tersebut akan diendapkan di tempat lain, seperti di sungai, waduk, saluran irigasi, daerah pertanian, dll. Erosi tanah oleh air dapat terjadi akibat tumbukan butiran tanah oleh air dan akibat aliran air permukaan. Arsyad (1989) menambahkan jika lereng permukaan tanah menjadi dua kali lebih curam, maka besarnya erosi menjadi 2,0 $-2,5$ kali lebih banyak. Erosi di daratan menyebabkan sedimentasi di pesisir dan menimbulkan berbagai dampak pada lingkungan perairan pesisir (Cui \& Li ,2011; Gao et al., 2012; Pratolongo et al., 2013, Giresse et al., 2013). Sedimentasi di pesisir menyebabkan pendangkalan perairan pesisir, menyebabkan perluasan daratan (tanah timbul) di sekitar muara sungai, serta berdampak negatif terhadap produktivitas perikanan di pesisir (Hidayat et al., 2013).

Tulisan ini bertujuan untuk mengetahui laju erosi tahunan pada Daerah Aliran Sungai (DAS) Citarum dari hulu hingga Muara seperti yang tersaji pada Gambar 1 dengan menggunakan model dinamik dengan memanfaatkan pemodelan Power Sim. 


\section{BAHAN DAN METODE}

Erosi yang terjadi pada suatu DAS dipengaruhi oleh tumbukan air hujan, kemiringan suatu tempat, sifat permukaan yang terkena tumbukan air hujan. Besarnya energi kinetik air hujan saat menyentuh permukaan suatu bidang sebanding dengan besarnya ukuran butiran air dan durasi hujan yang terjadi. Ukuran butiran air hujan sangat sulit ditentukan. Keberadaan energi kinetik yang dibangkitkan hujan dipresentasikan oleh data curah hujan.

Selain faktor besarnya energi kinetik dari hujan, sedimen yang tertranspor juga ditentukan oleh sifat material permukaan. Resistensi sedimen dipengaruhi oleh tekstur tanah, stabilitas agregat dan kapasitas resapan yang bergantung pada sifat organik dan kimiawi tanah. Sifat material permukaan dipresentasikan oleh jenis tanah $(\mathrm{K})$. Keadaan permukaan tanah memiliki kontribusi langsung terhadap meningkatnya proses erosi. Sebagai contoh dengan jenis tanah yang sama, permukaan tanah yang tandus akan berpotensi memperbesar laju erosi dibandingkan dengan permukaan tanah yang bervegetasi. Keadaan permukaan tanah diklasifikasikan dalam jenis tata guna tanah.

Butiran sedimen yang hancur akibat tumbukan air hujan akan berpindah dari satu posisi ke posisi lain oleh aliran limpasan permukaan. Kecepatan limpasan permukaan ditentukan oleh besarnya kemiringan permukaan. Besar nilai kecepatan aliran limpasan permukaan sebanding dengan besar kemiringan suatu permukaan (Ls) sebagai akibat dari gaya gravitasi. Sedimen yang tertranspor akan terdeposisi ketika kecepatan aliran permukaan berkurang.

Dengan menggunakan variabel Ls, $\mathrm{K}$ serta nilai koefisien tata guna lahan $\mathrm{C}$ dan nilai erosivitas $\mathrm{R}$, maka tingkat laju erosi DAS Citarum dapat diprediksi hingga 100 tahun kedepan. Dalam menentukan laju erosi tahunan DAS Citarum hingga 100 tahun kedepan dapat dilakukan dengan memanfaatkan pemodelan Power Sim 2.5. Perintah penjumlahan pada dasarnya bisa dilakukan di pemodelan power sim, dengan membuat bagan baru pada diagram alir.

Power Sim 2.5. merupakan perangkat lunak yang dapat melakukan simulasi perhitungan variabel data yang dimasukkan dan merupakan aplikasi perpanjangan (Extension Application) yang bisa diterima Operation System Windows karena perannya yang hampir sama seperti MS Excel ataupun MS Access. Power Sim 2.5. yang digunakan sebagai simulator kali ini berbasis academic bukan business, sehingga perangkat lunak dapat diperoleh dengan mudah (Open Access).

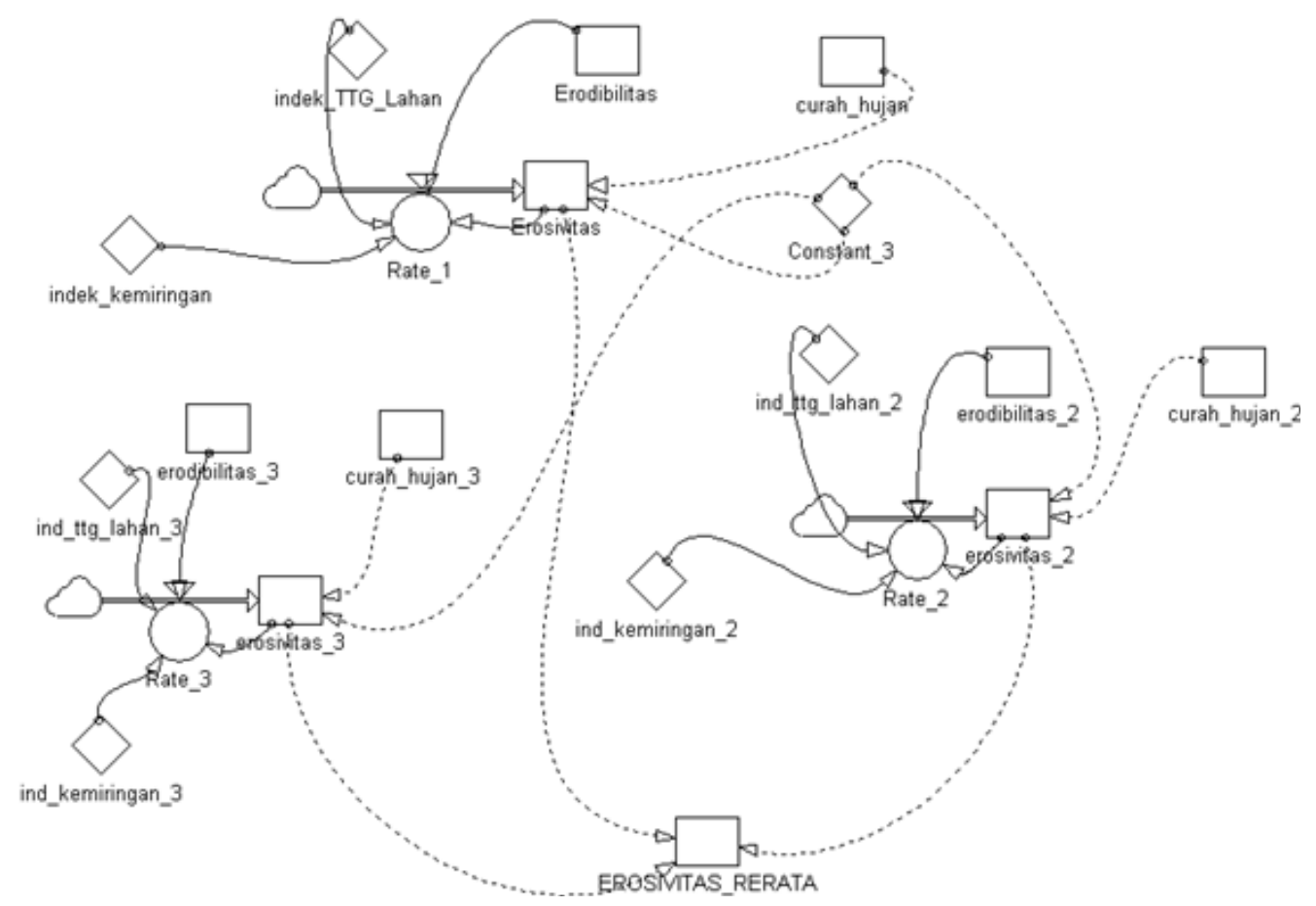

Gambar 2. Diagram alir disain pemodelan sistem dinamik laju erosi DAS Citarum.

Figure 2. Flowchart of the dynamic system modeling of the Citarum watershed erosion rate.

Analisis Laju Erosi DAS Citarum dari Hulu Hingga Kawasan Muara Menggunakan Sistem Dinamik - 
Sebagai gambaran dalam pemanfaatan model Power Sim, Gambar 2 menunjukkan diagram alir yang digunakan dalam prediksi laju erosi tahunan DAS Citarum pada tulisan ini.

\section{Laju Erosi}

Pada sebuah DAS, laju erosi tahunan pada umumnya dimodelkan secara empirik dengan Universal Soil Loss Equation (USLE), (Wischmeier \& Smith, 1978), dimana :

$$
E=L_{s} C K R
$$

dimana,

$E$ = laju erosi

$L_{s}=$ indeks kemiringan lereng

$C=$ nilai tata guna tanah

$K=$ erodibilitas

$R=$ erosivitas.

Secara empirik, persamaan laju erosi yang ditunjukkan oleh persamaan (1) dinyatakan dalam ton $/ \mathrm{km}^{2} /$ tahun.

\section{Indeks Kemiringan Lereng $\left(L_{s}\right)$}

Data SRTM digunakan untuk mendapatkan dua parameter geometrik yaitu panjang aliran (L) terlihat pada Gambar 3a dan kemiringan (S) nampak pada Gambar 3b. Data SRTM SRTM (Shuttle Radar Topographic Mission) merupakan data DEM (Digital Elevation Model) yang akurat dan terkini dengan resolusi spasial yang dapat diterima ketelitiannya. Data peta DEM sangat dibutuhkan untuk melakukan running model ini karena pada peta DEM, didapat elevasi pada lokasi tersebut dan elevasi merupakan sebagai salah satu variabel yang sangat penting terkait

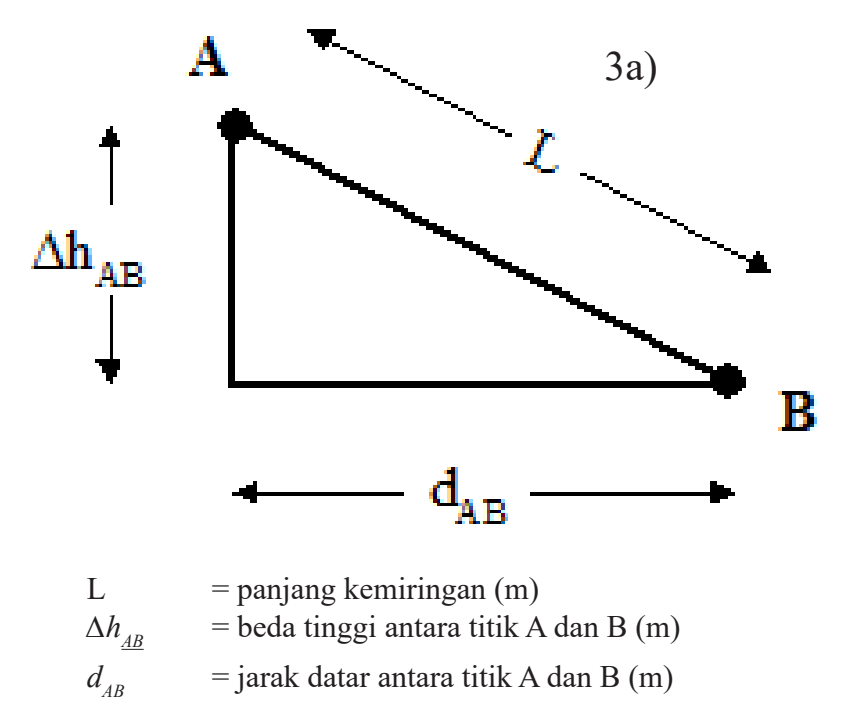

dengan parameter meteorologi, menurut Noor (2014) dalam Anindyaguna et al. (2017).

$L_{s}$ atau indeks kemiringan lereng yang didapat terbagi dalam 3 bagian yaitu indeks kemiringan lereng pada bagian hulu, tengah dan muara. $L_{s}$ dihitung dan ditentukan dengan formula empirik (Lu et al., 2003):

$L_{s}=\left(\frac{L}{k}\right)^{m}\left(k_{1} \sin ^{2} s+k_{2} \sin s+k_{3}\right)$

dimana,

$L=$ panjang profil kemiringan yang memiliki nilai tidak lebih besar dari 122m (Renard et al., 1997),

$m=$ indeks kemiringan

$k=$ persen kemiringan

$\mathrm{k}_{1}, \mathrm{k}_{2}, \mathrm{k}_{3}=$ merupakan konstanta-konstanta empirik.

$\mathrm{L}$ digambarkan pada Gambar 3a, m ditemtukan dalam

Tabel 1 sedangkan s digambarkan pada Fambar $3 b$.

Sedangkan $\mathrm{k}=22,1, \mathrm{k}_{1}=65,41, \mathrm{k}_{2}=4,56$ dan $\mathrm{k}_{3}=$ 0,065 .

Pada tulisan ini nilai $\mathrm{m}$ dan $\mathrm{s}$ yang digunakan dalam perhitungan sesuai dengan Tabel 1. dimana untuk bagian hulu nilai $\mathrm{m}=0,5$ dan $\mathrm{s} \geq 4,5$; bagian tengah $\mathrm{m}=0,35$ dan $\mathrm{s}=3$; bagian muara $\mathrm{m}=0,2$ dan $\mathrm{s}=0.5$.

\section{Indeks Tata Guna Tanah (C)}

Indeks tata guna tanah $(\mathrm{C})$ adalah suatu nilai dari hasil pengelompokan berdasarkan tutupan vegetasi atau keterbukaan lahan. Faktor $\mathrm{C}$ menunjukkan keseluruhan pengaruh dari vegetasi, seresah, keadaan permukaan tanah, dan pengelolaan lahan terhadap besarnya tanah yang hilang (erosi). Besarnya angka $\mathrm{C}$ tidak

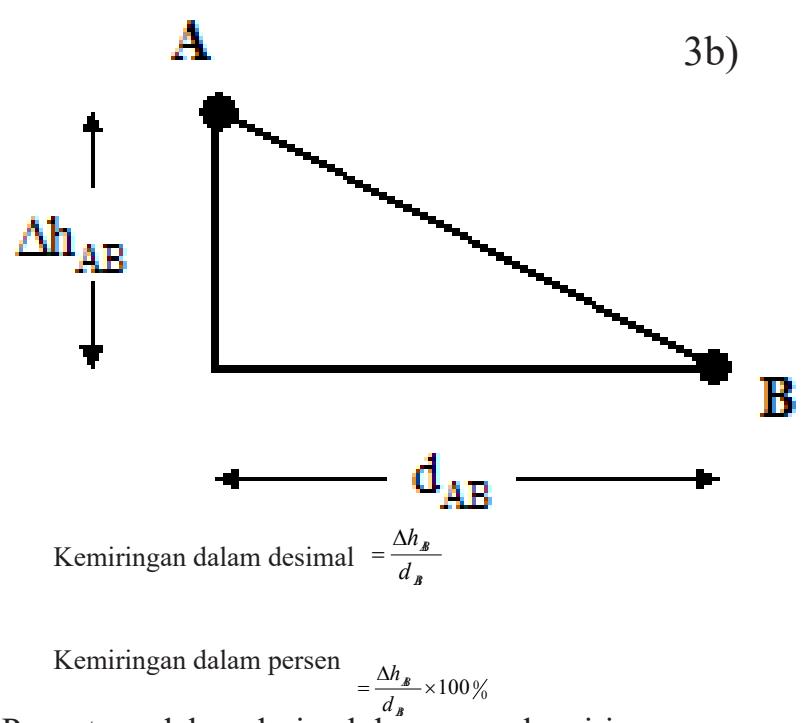

Gambar 3. a) Penentuan panjang profil kemiringan; b) Penentuan dalam desimal dan persen kemiringan.

Figure 3. a) Determination of the length of the slope profile; b) Determination in decimal and percent slope. 
Tabel 1. Tabel indeks kemiringan

Table 1. Slope index tablen

\begin{tabular}{ll}
\hline $\begin{array}{l}\text { Indeks } \\
\text { Kemiringan }\end{array}$ & $\begin{array}{l}\text { Persen } \\
\text { Kemiringan }\end{array}$ \\
\hline 0,2 & $0 \leq \mathrm{s}<1$ \\
0,3 & $1 \leq \mathrm{s}<3$ \\
0,4 & $3 \leq \mathrm{s}<4.5$ \\
0,5 & $\mathrm{~s} \leq 4.5$ \\
\hline
\end{tabular}

selalu sama bergantung perilaku lingkungan. Untuk keperluan tersebut badan air (kolam, danau, sungai, dil) dikategorikan sebagai tata guna tanah yang paling terlindungi sedangkan zona pertambangan sebagai zona tata guna tanah yang paling rentan terhadap erosi. Secara lebih lengkap, nilai tata guna tanah yang lainnya terletak diantara rentang nilai di atas dapat dilihat dalam Tabel 2.

Pada kajian ini nilai Indeks tata guna tanah (C) yang digunakan dalam perhitungan sesuai dengan Tabel 2 . dimana untuk bagian hulu nilai $\mathrm{C}=0,002$ berupa hutan ; bagian tengah $\mathrm{C}=0,005$ berupa kebun, lahan kering ; bagian muara $C=0,0001$ berupa sungai/kolam .

\section{Erodibilitas (K)}

Erodibilitas (K) menyatakan perpindahan partikel sedimen oleh karena pelepasan akibat energi kinetik yang ditimbulkan air hujan dan diangkut oleh air limpasan permukaan. Nilai erodibilitas diukur dan dikelompokkan berdasarkan resistensi pergerakan partikel material tanah yang dipengaruhi oleh tekstur tanah, stabilitas agregat, kapasitas peresapan yang merupakan sifat organik dan kimiawi tanah. Dalam hal ini, nilai erodibilitas ditentukan menurut beberapa jenis tanah. Dalam waktu singkat secara alamiah angka erodibilitas tanah sulit untuk berubah kecuali karena adanya perubahan alam yang bersifat ekstrim. Perubahan erodibilitas tanah yang signifikan berlangsung ketika terjadi hujan karena pada waktu tersebut partikel-partikel tanah mengalami perubahan orientasi dan karakteristik bahan kimia dan fisika tanah. Peranan tekstur tanah terhadap besar-kecilnya erodibilitas tanah adalah besar. Tanah dengan partikel agregat besar resistensinya terhadap daya angkut air larian juga besar karena diperlukan energi yang cukup besar untuk mengangkut partikel-partikel tanah tersebut. Sedangkan tanah dengan partikel agregat halus resisten terhadap pengelupasan karena sifat kohesi tanah tersebut juga besar. Partikel debu dan pasir halus kurang resisten dibandingkan jenis partikel tanah yang lainnya. Dengan demikian, tanah dengan kandungan debu tinggi mempunyai sifat erodibilitas besar. Tabel 3 menyatakan nilai K, sebagai berikut:

Pada kajian ini nilai Erodibilitas (K) yang digunakan dalam perhitungan sesuai dengan Tabel 3. dimana untuk bagian hulu nilai $\mathrm{K}=0,26$ dengan jenis tanah Andosol, grumosol ; bagian tengah $\mathrm{K}=0,23$ dengan jenis tanah Latosol; bagian muara $\mathrm{K}=0,20$ dengan jenis tanah Aluvial.

\section{Erosivitas (R)}

Erosivitas $\mathrm{R}$ adalah sebuah indeks yang menyatakan kapasitas gaya eksternal yang dibangkitkan oleh hujan untuk melepaskan partikel sedimen dari permukaan

Tabel 2. Nilai tata guna tanah (Trahan, 2003)

Table 2. Land use value (Trahan, 2003)

\begin{tabular}{ll}
\hline Jenis tata guna tanah & C \\
\hline Sungai/kolam/danau & 0,0001 \\
Zona Industri & 0,0005 \\
Pemukiman & 0,0007 \\
Vegetasi air/lahan basah & 0,001 \\
Hutan & 0,002 \\
Semak, belukar, taman & 0,003 \\
Kebun, lahan kering & 0,005 \\
Lahan terbuka & 0,4 \\
Zona pertambangan & 0,7 \\
\hline
\end{tabular}


tanah. Kemampuan air hujan sebagai penyebab terjadinya erosi bersumber dari laju dan distribusi tetesan air hujan, dimana keduanya mempengaruhi besarnya energi kinetik air hujan. Dengan demikian, dapat dikatakan bahwa erosivitas hujan sangat berkaitan dengan energi kinetis atau momentum, yaitu parameter yang berasosiasi dengan laju curah hujan atau volume hujan. Energi kinetik hujan inilah yang menjadi faktor utama terkelupasnya partikel-partikel tanah dari agregatnya.

$\mathrm{R}$ dinyatakan sebagai fungsi dari curah hujan bulanan $\mathrm{P}$ dalam persamaan Lenvain (DHV Consulting Engineers, 1989):

$$
R=2 . \mathcal{I} P^{1 . \mathfrak{B}}
$$

dimana,

$\mathrm{P}=$ curah hujan bulanan $(\mathrm{cm})$

Pada kajian ini nilai Erosivitas $\mathrm{R}$ yang digunakan dalam perhitungan sesuai dengan peta curah hujan yang dikeluarkan oleh BMG, seperti yang terlihat pada Gambar 7, dimana untuk bagian hulu nilai $\mathrm{R}=5000$ $\mathrm{mm} /$ tahun ; bagian tengah $\mathrm{R}=3000 \mathrm{~mm} /$ tahun ; bagian muara $\mathrm{R}=2000 \mathrm{~mm} /$ tahun.

\section{HASIL DAN PEMBAHASAN}

.Ilyas (2002) dalam Kurniawan et al. (2018) yang mengutip laporan Bank Dunia melaporkan bahwa pada tahun 1985 telah ada 1,9 juta hektar lahan kritis dengan tingkat laju erosi rata-rata 20-60 ton/ha/tahun. Angka ini jauh lebih besar daripada laju erosi rata-rata yang bisa ditoleransi yaitu 12,5 ton/ha/tahun (Arsyad, 1989). Peningkatan laju erosi makin tinggi dilaporkan dalam publikasi dari Poerbandono (2006), yang menyebutkan bahwa laju ekspor sedimen pada Sungai Citarum telah meningkat sebanyak 2 kali lipat yaitu dari 1,18 juta ton pada tahun 1993 menjadi 2,15 juta ton pada tahun 2003. Hal ini diduga disebabkan oleh berubahnya tata guna lahan di Daerah Aliran Sungai (DAS) Citarum dari perhutanan menjadi industri dan permukiman. Akibatnya, erosi lahan meningkat tajam dan tanah yang tergerus tersebut akan bergerak menuju sungai. Hal senada juga disampaikan BPDAS Citarum-Ciliwung (2009), yang menyebutkan, tingkat erosi wilayah DAS Citarum bagian muara tergolong besar, berkisar 5,483 ton/ha/tahun. Hal ini didukung oleh penelitian Aji (2014) dalam Paryono et al. (2017) melaporkan bahwa laju erosi Sub DAS Waduk Jatiluhur tahun 2013 disebutkan sebesar 27.032,7 ton/ha/ tahun, sehingga termasuk dalam kriteria kondisi sangat buruk.

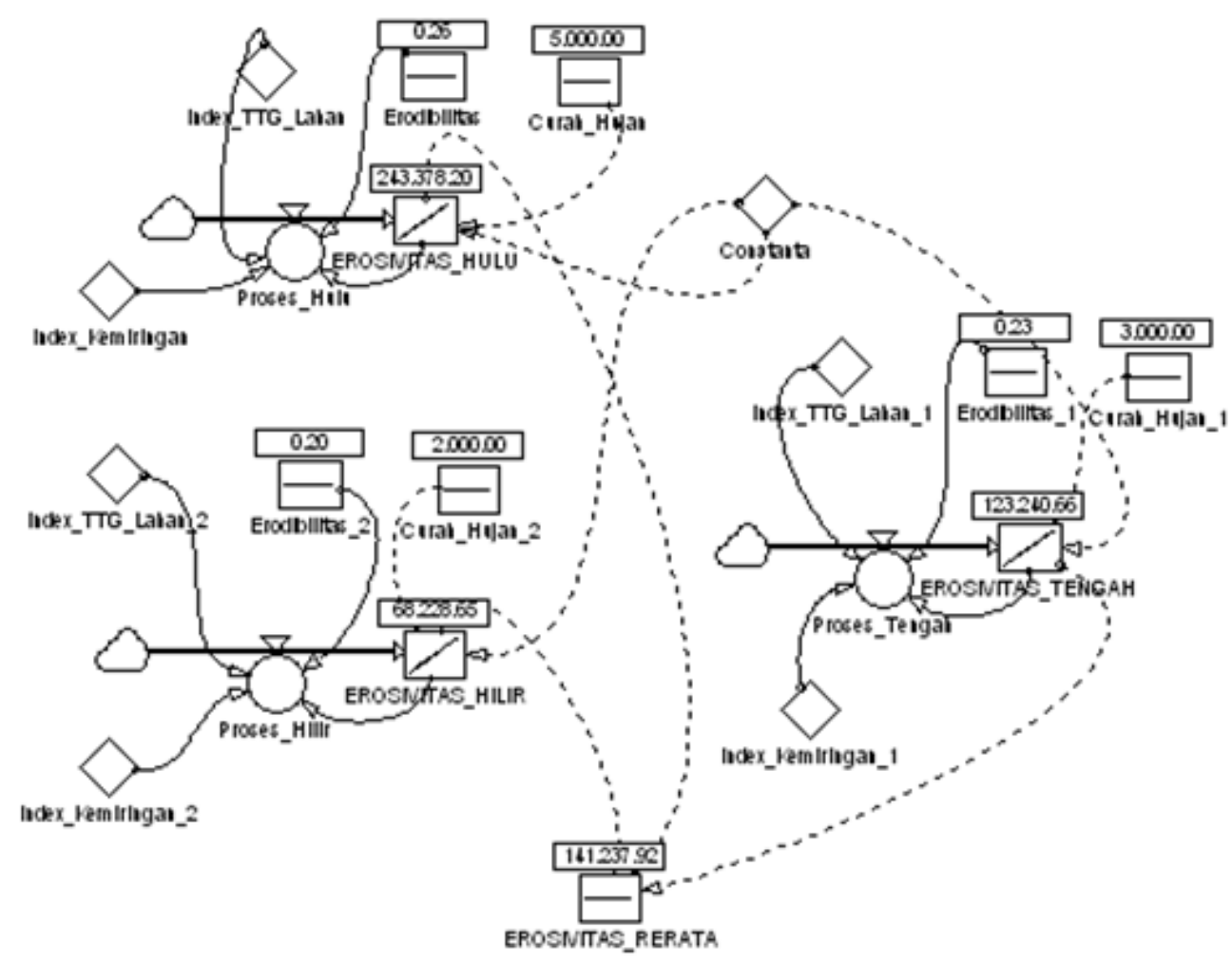

Gambar 4. Hasil komputasi pemodelan sistem dinamik laju erosi DAS Citarum.

Figure 4. Computational results of the modeling of the Citarum watershed erosion rate dynamic system. 
Hal berbeda ditunjukkan dari hasil komputasi pemodelan sistem dinamik laju erosi DAS Citarum memanfaatkan pemodelan Power Sim seperti yang tersaji pada Gambar 4. memperlihatkan adanya beberapa kecenderungan suatu area terhadap laju erosi. Dengan prediksi perhitungan 100 tahun kedepan laju erosi terkecil secara garis besar berada pada area muara, sementara laju erosi lebih besar dari 200 ton $/ \mathrm{km}^{2 /}$ tahun dengan prediksi perhitungan 100 tahun kedepan mendominasi area hulu DAS Citarum. Pemodelan ini secara detail dan berurutan memperlihatkan hasil perhitungan setiap tahunnya hingga tahun yang ke 100 dan ditampilkan dalam bentuk tabel waktu seperti yang disajikan pada Gambar 5 dan 6.

Gambar 5 memperlihatkan visualisasi saat proses komputasi berlangsung untuk simulasi laju erosi DAS Citarum 10 dan 50 tahun, dimana untuk hasil proses perhitungan dari tahun 0 yaitu disaat data dimasukan hingga tahun yang diinginkan, misalnya tahun ke 10 dan tahun ke 50 serta lanjut tahun ke 100 seperti yang tersaji pada Gambar 6. Dari hasil running model dapat diketahui prediksi tahun ke 10 untuk laju erosi DAS Citarum bagian hulu sebesar $237.749,99$ ton $/ \mathrm{km}^{2} /$ tahun, sedangkan pada tahun ke 50 sebesar 230.235,16 ton/ $\mathrm{km}^{2} /$ tahun, Sementara laju erosi lebih besar dari 200 ribu ton $/ \mathrm{km}^{2} /$ tahun dengan prediksi perhitungan 100 tahun kedepan mendominasi area hulu DAS Citarum dengan nilai $243.378,20$ ton $/ \mathrm{km}^{2} /$ tahun. Tingginya nilai laju erosi DAS Citarum bagian hulu tersebut sangat dipengaruhi oleh berubahnya tata guna lahan di Daerah Aliran Sungai (DAS) Citarum dari perhutanan menjadi industri dan permukiman. Akibatnya, erosi lahan meningkat tajam dan tanah yang tergerus tersebut akan bergerak menuju sungai.

Pada bagian tengahnya, laju erosi DAS Citarum untuk prediksi tahun ke 10 dan tahun ke 50 serta tahun ke 100 adalah $118.857,03 \mathrm{ton} / \mathrm{km}^{2} /$ tahun dan $120.785,72$ ton $/ \mathrm{km}^{2} /$ tahun serta $123.240,66$ ton $/ \mathrm{km}^{2} /$ tahun. Hasil perhitungan ini sangat terkait dengan terjadi perubahan ekstrem di bagian selatan Jawa Barat (sekitar hulu sungai Citarum) berupa konversi hutan menjadi tanah terbuka (semak, belukar atau lahan kering) pada tahun 1994 hingga 2001. Konversi hutan menjadi lahan terbuka dengan luas yang memiliki dampak spasial yang berarti berada pada wilayah tersebut menyebabkan peningkatan laju ekspor sedimen tahunan yang melebihi 100 ton $/ \mathrm{km}^{2}$ (Poerbandono, 2006).

Adapun untuk hasil perhitungan laju erosi DAS Citarum bagian muara dengan prediksi tahun ke 10 dan tahun ke 50 serta tahun ke 100, masing-masing sebesar $68.204,09$ ton $/ \mathrm{km}^{2} /$ tahun dan $68.215,01$ ton/ $\mathrm{km}^{2} /$ tahun serta $68.228,65$ ton $/ \mathrm{km}^{2} /$ tahun. Hasil berbeda beda banyak dilaporkan untuk laju erosi DAS Citarum bagian muara ini , mulai dari laporan Bank Dunia yang menyatakan tingkat laju erosi rata-rata 20-

\begin{tabular}{||cr|r|r|r||}
\hline \hline Time & EROSIMTAS_HULU & EROSIMTAS_TENGAH & EROSIMTAS_HILIR & | \\
0 & 237.132 .72 & 118.379 .69 & 68.201 .37 & \\
\hline 1 & 237.194 .37 & 118.427 .33 & 68.201 .64 & \\
\hline 2 & 237.256 .04 & 118.475 .00 & 68.201 .91 & \\
\hline 3 & 237.317 .73 & 118.522 .69 & 68.202 .18 & \\
\hline 4 & 237.379 .43 & 118.570 .39 & 68.202 .46 & \\
\hline 5 & 237.441 .15 & 118.618 .12 & 68.202 .73 & \\
\hline 6 & 237.502 .89 & 118.665 .86 & 68.203 .00 & \\
\hline 7 & 237.564 .64 & 118.713 .62 & 68.203 .27 & \\
\hline 8 & 237.626 .40 & 118.761 .41 & 68.203 .55 & \\
\hline 9 & 237.688 .19 & 118.809 .21 & 68.203 .82 & \\
\hline 10 & 237.749 .99 & 118.857 .03 & 68.204 .09 & \\
\hline \hline
\end{tabular}

\begin{tabular}{||cr|r|r||}
\hline Time & EROSIMTAS_HULU & EROSIMTAS_TENGAH & EROSIMTAS_HILIR \\
\hline 40 & 239.611 .44 & 120.300 .63 & 68.212 .28 \\
\hline 41 & 239.673 .74 & 120.349 .05 & 68.212 .55 \\
\hline 42 & 239.736 .06 & 120.397 .50 & 68.212 .82 \\
\hline 43 & 239.798 .39 & 120.445 .96 & 68.213 .10 \\
\hline 44 & 239.860 .74 & 120.494 .43 & 68.213 .37 \\
\hline 45 & 239.923 .10 & 120.542 .93 & 68.213 .64 \\
\hline 46 & 239.985 .48 & 120.591 .45 & 68.213 .92 \\
\hline 47 & 240.047 .88 & 120.639 .99 & 68.214 .19 \\
\hline 48 & 240.110 .29 & 120.688 .55 & 68.214 .46 \\
\hline 49 & 240.172 .72 & 120.737 .12 & 68.214 .73 \\
\hline 50 & 240.235 .16 & 120.785 .72 & 68.215 .01 \\
\hline \hline
\end{tabular}

Gambar 5. Visualisasi saat proses komputasi berlangsung untuk simulasi laju erosi DAS Citarum 10 dan 50 tahun. Figure 5. Visualization during the computational process for simulating the erosion rate of the Citarum watershed 10 and 50 years. 


\begin{tabular}{|c|c|c|c|c|}
\hline Time & EROSIMTAS_HULU & EROSIMTAS_TENGAH & EROSIMTAS_HILIR & \\
\hline 90 & 242.746 .32 & 122.745 .71 & 68.225 .92 & $=$ \\
\hline 91 & 242.809 .43 & 122.795 .12 & 68.226 .19 & \\
\hline 92 & 242.872 .56 & 122.844 .54 & 68.226 .47 & \\
\hline 93 & 242.935 .71 & 122.893 .99 & 68.226 .74 & \\
\hline 94 & 242.998 .87 & 122.943 .45 & 68.227 .01 & \\
\hline 95 & 243.062 .05 & 122.992 .94 & 68.227 .29 & \\
\hline 96 & 243.125 .25 & 123.042 .44 & 68.227 .56 & \\
\hline 97 & 243.188 .46 & 123.091 .97 & 68.227 .83 & \\
\hline 98 & 243.251 .69 & 123.141 .51 & 68.228 .11 & \\
\hline 99 & 243.314 .93 & 123.191 .08 & 68.228 .38 & \\
\hline 100 & 243.378 .20 & 123.240 .66 & 68.228 .65 & 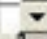 \\
\hline
\end{tabular}

\begin{tabular}{|c|r|r|r|r||}
\hline Time & EROSIMTAS_HULU & EROSIMTAS_TENGAH & EROSIMTAS_HILIR & ROSIMTAS_RERATA \\
\hline 0 & 237.132 .72 & 118.379 .69 & 68.201 .37 & 141.237 .92 \\
\hline 10 & 237.749 .99 & 118.857 .03 & 68.204 .09 & 141.237 .92 \\
\hline 20 & 238.368 .86 & 119.336 .29 & 68.206 .82 & 141.237 .92 \\
\hline 30 & 238.989 .34 & 119.817 .49 & 68.209 .55 & 141.237 .92 \\
\hline 40 & 239.611 .44 & 120.300 .63 & 68.212 .28 & 141.237 .92 \\
\hline 50 & 240.235 .16 & 120.785 .72 & 68.215 .01 & 141.237 .92 \\
\hline 60 & 240.860 .51 & 121.272 .77 & 68.217 .74 & 141.237 .92 \\
\hline 70 & 241.487 .48 & 121.761 .77 & 68.220 .46 & 141.237 .92 \\
\hline 80 & 242.116 .08 & 122.252 .75 & 68.223 .19 & 141.237 .92 \\
\hline 90 & 242.746 .32 & 122.745 .71 & 68.225 .92 & 141.237 .92 \\
\hline 100 & 243.378 .20 & 123.240 .66 & 68.228 .65 & 141.237 .92 \\
\hline \hline
\end{tabular}

Gambar 6. Visualisasi saat proses komputasi berlangsung untuk simulasi laju erosi DAS Citarum 100 tahun dan rerata keseluruhan area tiap tahun.

Figure 6. Visualization during the computational process for simulating the erosion rate of the Citarum watershed for 100 years and the average of the entire area each year.

60 ton/ha/tahun, dikarenakan pada tahun 1985 telah ada 1,9 juta hektar lahan kritis (Ilyas, 2002), serta BPDAS Citarum-Ciliwung (2009), yang menyebutkan, tingkat erosi wilayah DAS Citarum bagian muara tergolong besar, berkisar 5,483 ton/ha/tahun, hingga penelitian Aji (2014) melaporkan bahwa laju erosi Sub DAS Waduk Jatiluhur tahun 2013 disebutkan sebesar 27.032,7 ton/ha/tahun. Sangat bervariasinya hasil perhitungan untuk laju DAS Citarum bagian muara ini kemungkinan dikarenakan metode perhitungan yang digunakan berbeda atau input data variabel waktu yang digunakan berbeda atau akibat terjadinya perubahan iklim sehingga standar data variabel curah hujan yang diberikan berbeda serta kemungkinan pengaruh terjadi dinamika sedimentasi oleh berbagai faktor di wilayah pesisir seperti diungkapkan Dyer (1986) bahwa penambahan luas sedimentasi yang besar dari 2008 sampai 2010 di sekitar muara Sungai Citarum tidak semata disebabkan perubahan penggunaan lahan, namun terjadinya dinamika sedimentasi oleh berbagai faktor di wilayah pesisir juga sangat mempengaruhinya.

Selain menyajikan laju erosi DAS Citarum prediksi perhitungan 100 tahun kedepan pada Gambar 6. juga ditampilkan nilai rerata laju erosi DAS Citarum prediksi perhitungan 100 tahun kedepan sebesar $141,237,92$ ton $/ \mathrm{km}^{2} /$ tahun.
Pada dasarnya analisis laju erosi DAS Citarum dari hulu hingga kawasan muara menggunakan model dinamik dengan memanfaatkan pemodelan Power Sim ini merupakan simulasi perhitungan sederhana yang bisa dijadikan tolak ukur untuk mengetahui laju erosi DAS Citarum dari hulu hingga kawasan muara serta dapat dijadikan patokan dalam pengelolaan tata guna lahan kawasan DAS Citarum dari hulu hingga Muara. Hal ini dimungkinkan karena variabel masukan menggunakan pemodelan secara empirik dengan Universal Soil Loss Equation (USLE), dimana variabel masukan berupa indeks kemiringan lereng DAS, indeks tata guna tanah, indeks jenis tanah dan indeks curah hujan merupakan nilai konstanta dan baku serta hasil penelitian bertahun tahun. Indeks kemiringan lereng DAS Citarum diperoleh dengan mengekstraksi data DEM (Digital Elevation Model) DAS Citarum. Indeks tata guna tanah ditentukan dengan memberikan nilai pada setiap kelompok aktifitas penggunaan atas tanah terhadap besaran pengaruh erosi. Indeks jenis tanah disusun berdasarkan tingkat resistensi beberapa jenis tanah terhadap laju erosi, sedangkan indeks curah hujan diturunkan dari rata-rata curah hujan tahunan seperti yang tersaji pada Gambar 7.

Hasil analisis spasial dan temporal untuk curah hujan rerata pada penelitian ini didasarkan dari pengolahan 


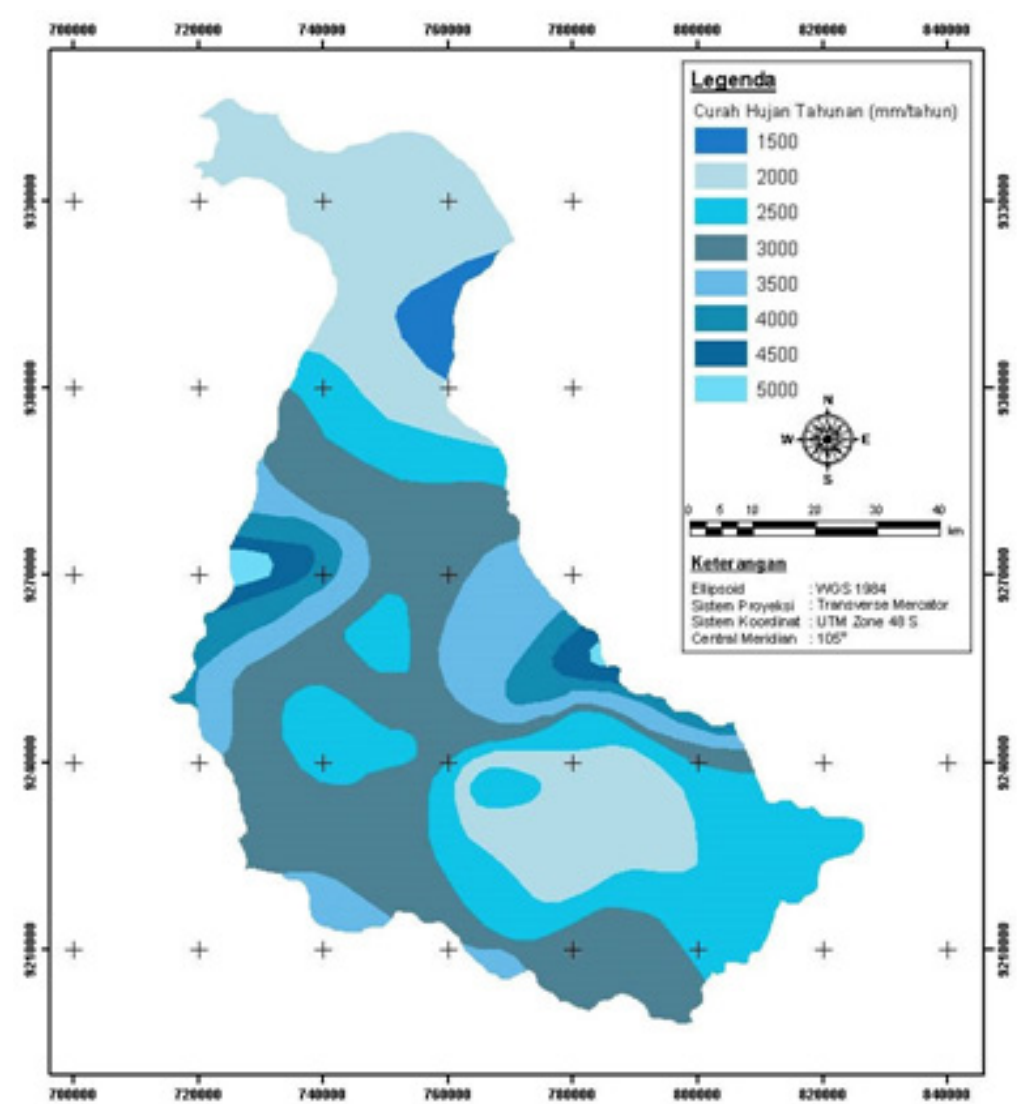

Gambar 7. Hasil analisis spasial dan temporal rerata curah hujan. Figure 7. Results of spatial and temporal analysis of mean rainfall.

data Peta Curah Hujan rerata tahunan yang merupakan hasil kerjasama Badan Koordinasi Survei dan Pemetaan Nasional (Bakosurtanal) dan Badan Meteorologi dan Geofisika (BMG), dengan sumber data Peta Rupabumi skala 1:1000000 terbitan Bakosurtanal tahun 1991, Peta Administrasi skala 1:1000000 dan data rerata curah hujan tahunan (1961-1990) terbitan BMG. Berdasarkan data rerata curah hujan dengan rentang waktu 30 tahun tersebut, tentunya nilai indeks curah hujan yang diturunkan untuk area DAS Citarum dapat dijadikan nilai patokan untuk analisa lebih lanjut, terkait kemungkinan adanya kondisi perubahan iklim yang ekstrim.

Adapun terdapat variasi nilai hasil perhitungan, terutama pada kawasan muara, hal ini sangat dipengaruhi oleh faktor alam mencari kesetimbangan. Dapat dicontohkan ketika nilai laju erosi DAS Citarum pada kawasan muara lebih besar dari hasil simulasi perhitungan sederhana kali ini, hal tersebut sangat dimungkinkan karena terjadi perubahan cuaca yang ekstrim sehingga curah hujan lebih tinggi dari biasanya atau terjadinya perubahan tata guna lahan yang signifikan pada DAS Citarum. Dampak yang timbul atas hal tersebut adalah besarnya sedimen yang mensuplai kawasan pesisir lebih dari biasanya dan secara otomatis arus dan gelombang laut akan menahan dan mengendapkan sedimen berlebih tersebut di kawasan muara agar tercapai kesetimbangan. Begitu juga sebaliknya, pada saat pengelolaan tata guna lahan sangat baik didukung dengan kondisi kemarau yang cukup ekstrim maka nilai laju erosi DAS Citarum pada kawasan muara akan lebih kecil dari hasil simulasi perhitungan sederhana kali ini, hal tersebut akan berdampak pada terjadinya abrasi pada kawasan muara akibat dari kurang nya suplai sedimen pada kawasan pesisir.

\section{KESIMPULAN DAN SARAN}

Berdasarkan analisa terkait nilai indeks konstanta dan baku yang diberikan pada variabel masukan dalam pembangunan model dinamik dengan simulasi perhitungan sederhana memanfaatkan pemodelan Power Sim, serta adanya korelasi antara hasil perhitungan laju erosi dengan informasi kejadian yang disebutkan dalam diskusi, maka simulasi perhitungan sederhana ini bisa dijadikan tolak ukur untuk mengetahui laju erosi DAS Citarum dari hulu hingga kawasan muara serta dapat dijadikan patokan dalam 
pengelolaan tata guna lahan kawasan DAS Citarum dari hulu hingga Muara.

Dari perhitungan laju erosi DAS Citarum yang telah dilaksanakan, didapatkan informasi besaran laju erosi pada tiap area atau bagian DAS Citarum, dimana pada daerah hulu DAS Citarum memiliki variabilitas laju erosi tahunan dengan dominasi lebih besar dari 240 ton $/ \mathrm{km}^{2} /$ tahun, untuk daerah tengah DAS Citarum laju erosi tahunan berkisar pada 123 ton $/ \mathrm{km}^{2} /$ tahun, sedangkan pada daerah muara memiliki laju erosi dominan antara 68 ton $/ \mathrm{km}^{2} /$ tahun,.

\section{UCAPAN TERIMA KASIH}

Terima kasih disampaikan kepada Pusat Riset Kelautan, BRSDM, KKP dan Pusat Hidro Oseanografi TNI AL serta Sekolah Tinggi Teknologi TNI Angkatan Laut yang telah memberikan kesempatan studi pada kedua penulis yang merupakan contributor utama pada tulisan ini. Ucapan terima kasih juga disampakan kepada Prof. Dr. Ignasius Loyola Setyawan Purnama dan Prof. Dr. rer. nat Muh Aris Marfai yang membimbing penulis dalam studi, Dr. -ing. Widodo Setyo Pranowo atas arahan yang diberikan pada tulisan ini, Erish Widjanarko, S.T., Joko Subandriyo, S.T, dan segenap tim Editor Jurnal Kelautan Nasional yang banyak membantu hingga terselesaikannya tulisan ini.

\section{DAFTAR PUSTAKA}

Aji, H. G. (2014). Evaluasi laju sedimentasi Waduk Jatiluhur. Bogor: IPB Press.

Anindyaguna M., Suharyanto., \& Tedjakusuma, T. (2017), Model Sedimentasi pada Sungai Citarum dan Anak Sungai Tarum Barat dan Tarum Timur. Jurnal Teknik Lingkungan, 23(2), 43-52.

Arsyad, S. (1989). Konservasi Tanah dan Air. Bogor, Indonesia: IPB.

BP DAS Citarum-Ciliwung. (2009). Rencana pengelolaan DAS Citarum terpadu. Bogor.

Byrknes, A., \& Cover, J. (1996). Quick Tour in Power Sim AS, Power Sim AS, Geo Grafik Design Group, Springfield, Virginia.

Cui, B., \& Li, X. (2011). Coastline change of the Yellow River estuary and its response to the sediment and runoff (1976-2005). Geomorphology,
$127(1-2), 32-40$.

DHV Consulting Engineer, (1989). Study on Catchment Preservation and Environmental Impact of the Water Supply Projects of Bandung and Sukabumi, Ministry of Public Work, Rep. Of Indonesia.

Dyer, K. R. (1986). Coastal and estuarine Sediment Dynamics. $\mathrm{Xv}+342$ p. Chishester, New York, Brisbane, Toronto, Singapore : Wiley Interscience.

Gao, J. H., Jun, L. I., Wang, H., Bai, F. L., Cheng Y. \& Wang, Y. P. (2012). Rapid changes of sediment dynamic processes in Yalu River Estuary under anthropogenic impacts. International Journal of Sediment Research, 27(1), 37-49. DOI:10.1016/ S1001-6279(12)60014-6.

Giresse, P., Bassetti, M. A., Pauc, H., Gaullier, V., Déverchère, J., Bracene, R., \& Yelles, A. (2013). Sediment accumulation rates and turbidite frequency in the eastern Algerian margin. An attempt to examine the triggering mechanisms. Sedimentary Geology, 294, 266-281. https://doi .org/10.1016/j.sedgeo.2013.06.005

Hidayat, Y., Kukuh, M., Enni, D. W., \& Diah, R. (2013). Pencirian debit sungai Citarum hulu (The Characteristics of River Discharge of Citarum Hulu). Jurnal Ilmu Pertanian Indonesia (JIPI), 18(2), 109-114.

Ilyas, M. A. (2002). Sedimentasi dan Dampaknya pada DPS Citarum Hulu. Jurnal Teknologi Lingkungan, 3(2), 159-164.

Kartasapoetra. (1991). Teknologi Konservasi Tanah dan Air, Rineka Cipta. Jakarta.

Kelompok Kerja Erosi dan Sedimentasi. (2002). Kajian Erosi dan Sedimentasi DAS Teluk Balikpapan Kalimantan Timur, Proyek Pesisir, TE-02/13-I, CRC/URI, Jakarta.

Kurniawan V., Setyarini, N. L. S. E., Kushartomo, W., Tajudin, A.N., \& Sandjaya, A. (2018). Citarum Harum - Investigasi Lapangan untuk Mengukur Tingkat Sedimentasi pada Sungai Citarum. Jurnal Bakti Masyarakat Indonesia, 1(2), 119126.

Lu, H., Moran, C. J., \& Prosser, I. P. (2003). Modelling 
Sediment Delivery Ratio over the Murray Darling Basin, CSIRO Land and Water, Canberra, Australia.

Noor, H., Vafakhah, M., Taheriyoun, M., \& Mogadhashi, M. (2014). Hydrology modelling in Taleghan mountainous watershed using SWAT. Journal of Water and Land Development, 20(1-3), 11-18.

Paryono., Damar, A., Susilo, S. B., Dahuri, R., \& Suseno, H. (2017). Sedimentasi Delta Sungai Citarum, Kecamatan Muara Gembong, Kabupaten Bekasi, Jurnal Penelitian Pengelolaan Daerah Aliran Sungai. Journal of Watershed Management Research, 1(1), 15-26.

Paryono, Sukoraharjo, S. S., Damar, A., Susilo, S. B., Dahuri, R., \& Suseno, H. (2016). Analysis Dinamika Spasial dan Temporal Penggunaan Lahan dan Implikasinya Terhadap Sedimentasi di Wilayah Pesisir DAS Citarum. Jurnal Kelautan Nasional, 11(3), 189-200.

Poerbandono, A. B. (2006). Evaluasi Perubahan Perilaku Erosi Daerah Aliran Sungai Citarum Hulu dengan Pemodelan Spasial. Jurnal Infrastruktur dan Lingkungan Binaan, 2(2), 2128.

Pratolongo, P., Mazzon, C., Zapperi, G., Piovan, M. J. \& Brinson, M. M. (2013). Land cover changes in tidal salt marshes of the Bahía Blanca estuary (Argentina) during the past 40 years. Estuarine, Coastal and Shelf Science, 133(20 November 2013), 23-31.

Trahan, N. (2003). Modelling Sediment and Contaminant Pathyways to the Cedar River, Jones, Edmunds \& Associates. Florida.

Wischmeier, W. H., \& Smith, D. D. (1978). Predicting RainfallErosion Losses -AGuide to Conservation Planning, US Dept. Of Agricultural Handbook 537. 
